disconnection of intracranial pial single-channel arteriovenous fistulae. Neurosurgery 2001;49:1351-1363.

4. Nelson K, Nimi Y, Lasjaunias P, et al. Endovascular embolization of congenital intracranial pial arteriovenous fistulas. Neuroimaging Clin N Am 1992;2:309-317.

5. Lasjaunias P, Ter Brugge KG, Berenstein A. Cerebral arteriovenous fistulas. In: Heilmann U (Ed). Surgical Neuroangiography 3. $2^{\text {rd }}$ ed. New York: Springer Verlag, 2006:227-270.

\section{FISTULA ARTERIOVENOSA PIAL NA FOSSA POSTERIOR}

'MD, Residente de Radiologia pelo Centro Diagnóstico por Imagem de Vitória (CDI), Vitória ES, Brazil; ${ }^{2} \mathrm{MD}$, PhD Neurocirurgião e Neurorradiologista
Intervencionista - Hospital Metropolitano e Vitória Apart Hospital, Serra ES, Brazil. Hospital Central de Vitória e Centro Integrado de Atenção a Saúde, Vitória ES, Brazil; ${ }^{3} \mathrm{MD}$, Residente de Radiologia, CDI; ${ }^{4} \mathrm{MD}$, Neurocirurgião e Neurorradiologista Intervencionista, Hospital Metropolitano e Vitória Apart Hospital, Serra ES, Brazil. Hospital Central de Vitória e Centro Integrado de Atenção a Saúde, Vitória ES, Brazil; ${ }^{5} \mathrm{MD}$, Neurocirurgião, Hospital Metropolitano e Vitoria Apart Hospital, Serra ES, Brazil. Hospital Central de Vitória e Centro Integrado de Atenção a Saúde, Vitória ES, Brazil.

Correspondence: Leandro de Assis Barbosa - Rua Nicolau Von Schilgem 100/1103 - 29065-130 Vitória ES - Brasil. E-mail: leandro.assisbarbosa@gmail.com Received 1 March 2011, received in final form 7 April 2011. Accepted 14 April 2011.

\title{
Extradural cavernous hemangioma of thoracic spine
}

\author{
Apio Antunes ${ }^{1}$, Mateus Felipe Lasta Beck², Atahualpa Caue Paim Strapasson², \\ André Cerutti Franciscatto², Mateus Franzoi²
}

Cavernous hemangioma of the central nervous system is a vascular malformation which is a developmental hamartoma, also known as cavernoma or cavernous malformation or venous angioma ${ }^{1}$.

Cavernomas may affect any segment of the neuraxis. Most of these malformations are intracranial: supratentorial compartment is a site usually affected ${ }^{2,3}$. Pure spinal epidural cavernomas represent approximately $12 \%$ of spinal cavernous anomalies ${ }^{4}$ and the thoracic segment is the most frequently affected ${ }^{5}$. There are approximately 80 cases of epidural cavernous hemangioma published in the literature ${ }^{4,5}$.

We report on a case of thoracic extradural cavernous hemangioma, with emphasis on the clinical aspects.

\section{CASE}

A 63-years-old female caucasian patient with a previous history of cryptogenic epilepsy was referred to our emergency department with complaints of a one year history of gait ataxia, numbness and dysesthesia in both lower limbs. In the last 2 months, she also noticed reduced strength in the lower limbs.

Neurological examination showed reduced strength in the lower limbs, grade $4 / 5$ in the right lower limb and grade $3 / 5$ in the left one. There was reduced sensation for all sensory modalities below the T10-11 dermatomes. There was also lower limb hyperreflexia and hypertonia, with bilateral extensor plantar response.

An MRI showed an epidural space-occupying lesion involving the T9-T10 spinal canal levels and extending to

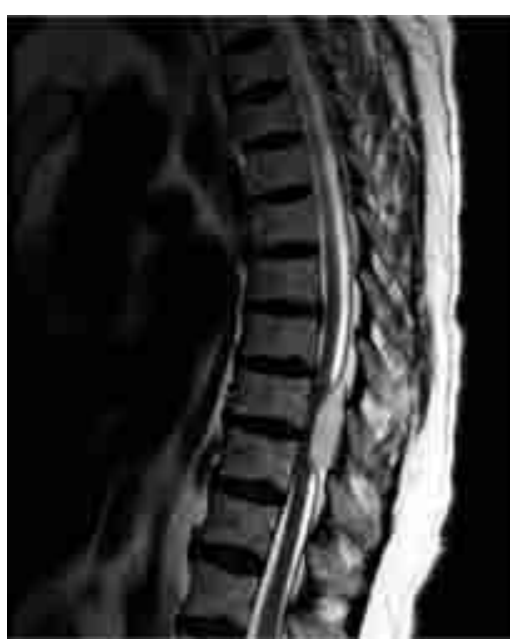

Figure. Preoperative MRI. Sagital T2-weighted image showing isodense lesion in the posterior extradural space at T9-T10 with ventral dislocation of the spinal cord.

the T9 left foramen, with an intense and homogeneous contrast enhancement (Figure).

The patient was submitted to a T9-T10 laminectomy, including a T9 left foraminectomy. A posterior soft and reddish epidural mass with a good cleavage plan was completely removed. The patient evolved with partial improvement of sensibility in both lower limbs and strength.

Histological examination revealed thin-walled blood vessels lined with a single layer of endothelial cells, surrounded by connective tissue. The microscopic appearance was compatible with cavernous hemangioma. 


\section{DISCUSSION}

Cavernoma is a benign tumor and it is considered a dysplasia of the vessels-forming mesoderm ${ }^{4}$. Cavernous hemangiomas in the vertebral, extradural, intradural extramedullary and intramedullary spaces are responsible for 3 to $16 \%$ of spinal vascular anomalies ${ }^{4,5}$.

Extradural cavernous hemangioma represent $4 \%$ of all spinal epidural lesions ${ }^{5}$. Modern diagnostic imaging techniques are increasing the number of diagnosis and its frequency may be more than previously reported in the medical literature ${ }^{5}$.

There are four clinical syndromes described: slow and progressive spinal cord syndrome, which is the most common form; acute spinal cord syndrome; back pain; and radiculopathy ${ }^{3}$.

Imaging diagnostic exams such as spine X-rays, myelography, CT and MRI are important for evaluating the relationship of the lesion with the surrounding anatomic structures ${ }^{1}$. Currently, MRI is the modality of choice ${ }^{5}$.

The treatment for these lesions is total removal of the tumor with microsurgical technique ${ }^{1}$.

\section{REFERENCES}

1. Hatiboglu MA, Iplikcioglu AC, Ozcan D. Epidural spinal cavernous hemangioma-case Report. Neurol Med Chir (Tokyo) 2006;46:455-458.

2. Goyal A, Singh AK, Gupta V, Tatke M. Spinal epidural cavernous haemangioma:a case report and review of literature. Spinal Cord 2002;40: 200-202.

3. Zevgaridis D, Buttner A, Weis S, Hamburger C, Reulen HJ. Spinal epidural cavernous hemangiomas. Report of three cases and review of the literature. J Neurosurg 1988;88:903-908.

4. Saringer W, Nobauer I, Haberler C, Ungersbock K. Extraforaminal, thoracic, epidural cavernous hemangioma:case report with analysis of magnetic resonance imaging characteristics and review of the literature. Acta Neurochir (Wien) 2001;43:1293-1297.

5. Santoro A, Piccirilli M, Bristot R, Norcia V, Salvati M, Delfini R. Extradural spinal cavernous angiomas: report of seven cases. Neurosurg Rev 2005;28: 313-319.

\section{HEMANGIOMA CAVERNOSO EXTRADURAL DA COLUNA TORÁCICA}

Neurosurgical Unit, Hospital de Clínicas de Porto Alegre, Porto Alegre RS, Brazil: ${ }^{1}$ Head of Neurosurgical Unit, Associate Professor of Neurosurgery, FAMED, UFRGS; ${ }^{2}$ Resident of Neurosurgery.

Correspondence: Apio Antunes - Unidade de Neurocirurgia / Serviço de Neurologia do HCPA - Rua Ramiro Barcelos 2350 / $2^{\circ}$ andar - 90035-903 Porto Alegre RS - Brasil. E-mail: apioantunes@gmail.com

Received 13 February 2011. Received in final form 31 November 2011. Accepted 7 April 2011.

\title{
Bilateral traumatic avulsion of abducens nerve
}

\author{
Bruno S.C. Lopes', Lazaro L.F. do Amaral', Higor G. Bezerra', \\ Ricardo M. Rogério', Antônio A. Zambon²
}

A 45-year-old previously healthy woman suffered a head trauma with neck hyperextension during bike exercise, losing consciousness for about 24 hours. Upon awakening, she presented bilateral lateral gaze palsy and convergent strabismus (Fig 1). No bone fracture was detected on CT studies (not shown). This clinical picture persisted unchanged for over one year and a MRI study done at our service showed bilateral avulsion of the sixth cranial nerve using FIESTA sequence (Fig 2A, $B, C$ and $D)$.

The abducens innervates the lateral rectus muscle, which is responsible for the horizontal lateral movement of the ocular globe. It has a long course, beginning at its nucleus, on the ventral pons, going through the pre-pontine cistern to its dural entry point on the petroclival region, coursing through Dorello's canal, beneath petroesphenoidal ligament, where it is covered by an envelope composed of one dural layer and one arachnoidal layer ${ }^{1}$ to the cavernous sinus, lateral to the internal carotid artery, reaching the superior orbital fissure and orbital apex. This long course makes it more susceptible to injuries.

Various different diseases can cause sixth nerve palsy, neoplasic and traumatic etiologies being more common in children, while vascular and idiopathic are responsible for the majority of cases in adult population ${ }^{2}$.

Traumatic injuries of abducens nerve are a wellknown consequence of severe head trauma, reported in

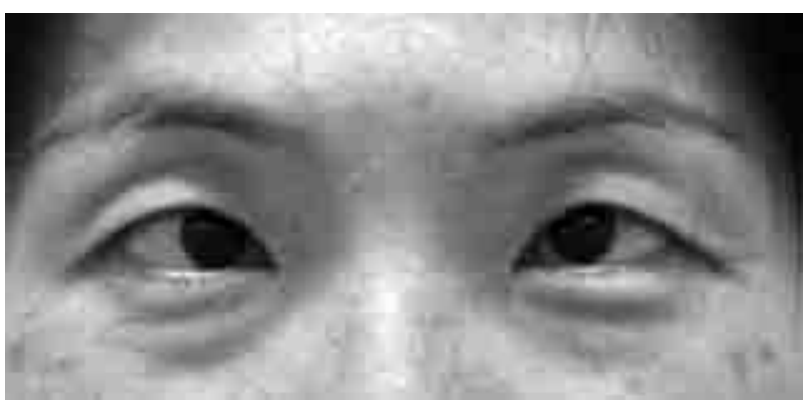

Fig 1. Convergent strabismus evidenced at physical examination 1 -year after head trauma. 